\title{
A Zoomorphic Antler Staff from an Early Neolithic Burial at Pushkinsky, the Orenburg Region
}

I describe a rare artifact-a staff with a zoomorphic finial, carved from the curved part of an elk antler. It was found in 1982 on a bank of the Tok River, in the western Orenburg region. The artifact was in a seated burial, discovered by chance. The archaeological context is described, and a cultural and chronological attribution is proposed. It is concluded that the burial is associated with the Early Neolithic Elshanka culture. Similar staffs were found mostly in Mesolithic and Neolithic burials in the forest zone of Eastern Europe. Radiocarbon analyses suggest that seated burials with zoomorphic antler staffs date to the interval from the 6th to the early $3 \mathrm{rd}$ millennium $B C$. The peculiar feature of the Pushkinsky specimen is that it likely depicts a horse rather than an elk, probably because the economy in the steppe and forest-steppe focused on horse hunting. Such artifacts were apparently ritual, and the practice could have originated in the steppe and forest-steppe from whence it spread to the forest zone.

Keywords: Zoomorphic staff, burial, Mesolithic-Neolithic, Southern Urals.

\section{Introduction}

A staff made of antler with zoomorphic finial has been discovered on the bank of the Tok River (Samara River basin), $500 \mathrm{~m}$ south of the modern settlement of Pushkinsky, in the Krasnogvardeisky District, Orenburg Region (Fig. 1). The present-day landscape of the area can be described as steppe; typical forest-steppes begin a little northerly. During the Holocene, the natural and climatic conditions in the western Orenburg region could have repeatedly changed towards greater humidity or greater aridity. Accordingly, owing to climate fluctuations, the boundary between the steppe and foreststeppe could have shifted from south to north or from north to south.

As has been established during research at the settlement of Ivanovskoye, in the immediate vicinity of Pushkinsky, the Neolithic and Chalcolithic in the Volga-Urals region corresponded to the Atlantic
Period. According to scholars, this was the stage of the second optimum of the Atlantic Period of the Holocene, distinguished by a humid and cool climate accompanied by increase in forestation of the region with pine and birch (Lavrushin, Spiridonova, 1995). These conclusions have been confirmed by the data on the paleofauna hunted by the inhabitants of the Ivanovskoye settlement during that period, which included elks, beavers, deer, badgers, otters, wild boars, and even bears; but the main objects of hunting were wild horses (Petrenko, 1995).

Studies at Ivanovskoye and other sites were carried out in 1977-1982 and in 2014-2015 (Morgunova, 1995, 2011; Morgunova et al., 2017). The archaeologists obtained the staff in 1982. A resident of Pushkinsky, V.N. Myachin, brought a bag of human bones, which he discovered on the Tok River bank, about $7 \mathrm{~km}$ upstream the Ivanovskoye. Bone remains included fragments of an antler object with a finial in the form of either an elk's or

Archaeology, Ethnology \& Anthropology of Eurasia 48/2 (2020) 14-21 E-mail: Eurasia@archaeology.nsc.ru (C) 2020 Siberian Branch of the Russian Academy of Sciences

(C) 2020 Institute of Archaeology and Ethnography of the Siberian Branch of the Russian Academy of Sciences 


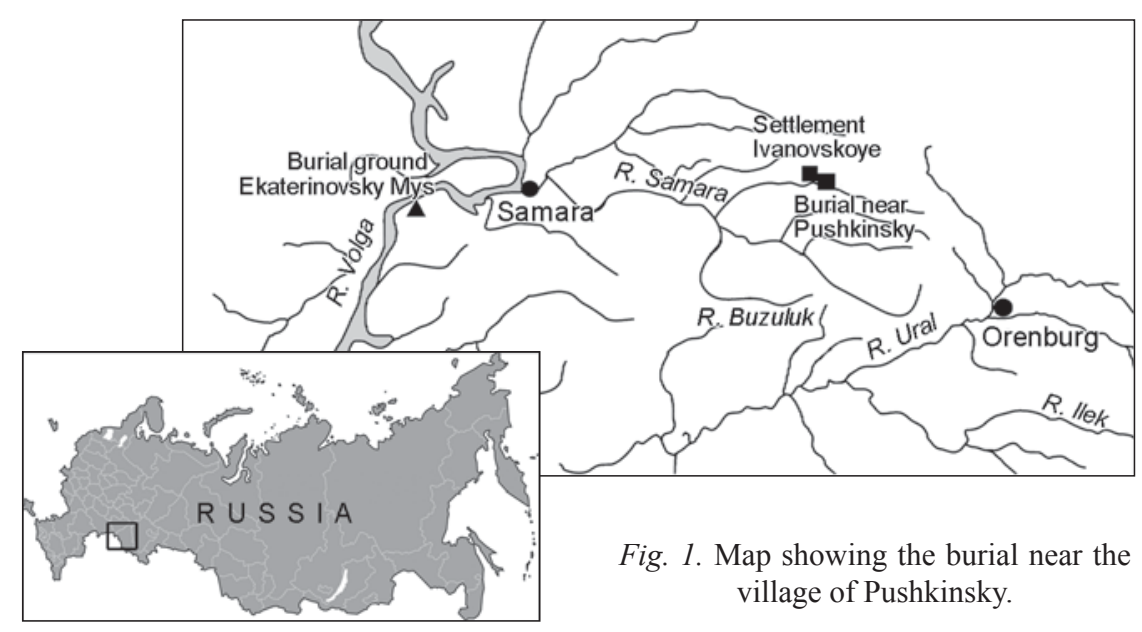

a horse's head. While identifying the type of animal, the opinions of specialists became divided; disagreement on this subject remains until today. Information about the find was published in the Journal Arkheologicheskiye otkrytiya 1982 goda (Morgunova, 1984); later, the staff was described by S.V. Bogdanov in his own interpretation (1992). Since then, the Pushkinsky staff (I believe that it should be named exactly thus, according to the place of discovery) has been mentioned in a number of studies on such items (Kashina, 2005; Zhulnikov, Kashina, 2010; Savchenko, 2018; and others). This staff should certainly be considered together with other elk-headed staffs, although it is separated quite far from them both territorially and chronologically. This explains the need to re-address this item, which is certainly an outstanding work of prehistoric art.

\section{Descriptions of the burial near Pushkinsky and the staff}

First, we should mention the place where the staff was discovered. There is no doubt that the item was in a burial. According to Myachin, while fishing on a steep bank, he saw, in a side view, a skeleton of a man "squatting", with his legs pulled to his chin. Since the ongoing archaeological excavations were well-known in the area, the burial was "lucky", and all evidence was carefully collected.

The location of the find was inspected by archaeologists. The height of the bank (cliff) above the level of the river reached $5 \mathrm{~m}$. An excavation ditch $4 \mathrm{~m}$ wide was made along the cliff. No remains of a burial ground have been found in the deposits. The following sequence of soil layers has been established. An even layer of dark gray humus $0.8 \mathrm{~m}$ thick, which did not contain any artifacts, was below the sod layer. Usually, in such layers, settlements from the Late Bronze Age have been found. This layer covered the buried soil, which consisted of light gray loam $1 \mathrm{~m}$ thick, without any finds. Next, there was a layer of brown loam of lumpy structure $0.9 \mathrm{~m}$ thick, under which pure layers of clay lay up to the surface of the water. The burial with the staff was located exactly in the last humus layer, at a depth of $3 \mathrm{~m}$ from the surface. Judging by the soil features and depth of deposition, this layer could have emerged during the Mesolithic or Early Neolithic. Scarce finds confirm the connection of the burial with that period. Five small fragments of undecorated pottery, pieces of ocher, flakes of flint, two fragments of microblades without traces of retouching, and a phalanx of a human toe were found during unearthing of the excavation ditch in this layer. Although the finds in the layer do not show clear diagnostic features, they can, together with lithological data, be compared to similar evidence from the Mesolithic Staro-Tok site and the Neolithic layer at the Ivanovskoye settlement, which contained the items from the Early Elshanka culture (Morgunova, 1995).

All anthropological evidence from the burial near Pushkinsky was transferred to the Institute of Ethnography of the USSR Academy of Sciences. According to the identification by R.A. Mkrtchyan, anthropologist from this Institute, the skeleton belonged to a male of the protoCaucasoid type, 45-50 years of age. Unfortunately, the interpretation of the evidence was suspended; data were not described, and the finds were lost.

The staff was undoubtedly a creation of an outstanding artist of his time (Fig. 2, 3). The sculpture was made in the style merging the image of the animal with an object for a utilitarian or religious purpose, which style was widespread during the Mesolithic and Neolithic. The staff was carved of the curved part of an elk antler (as identified by V.N. Danilchenko, archaeozoologist from the Institute of Archaeology of the USSR Academy of Sciences). The length of the artifact from the bend to the 


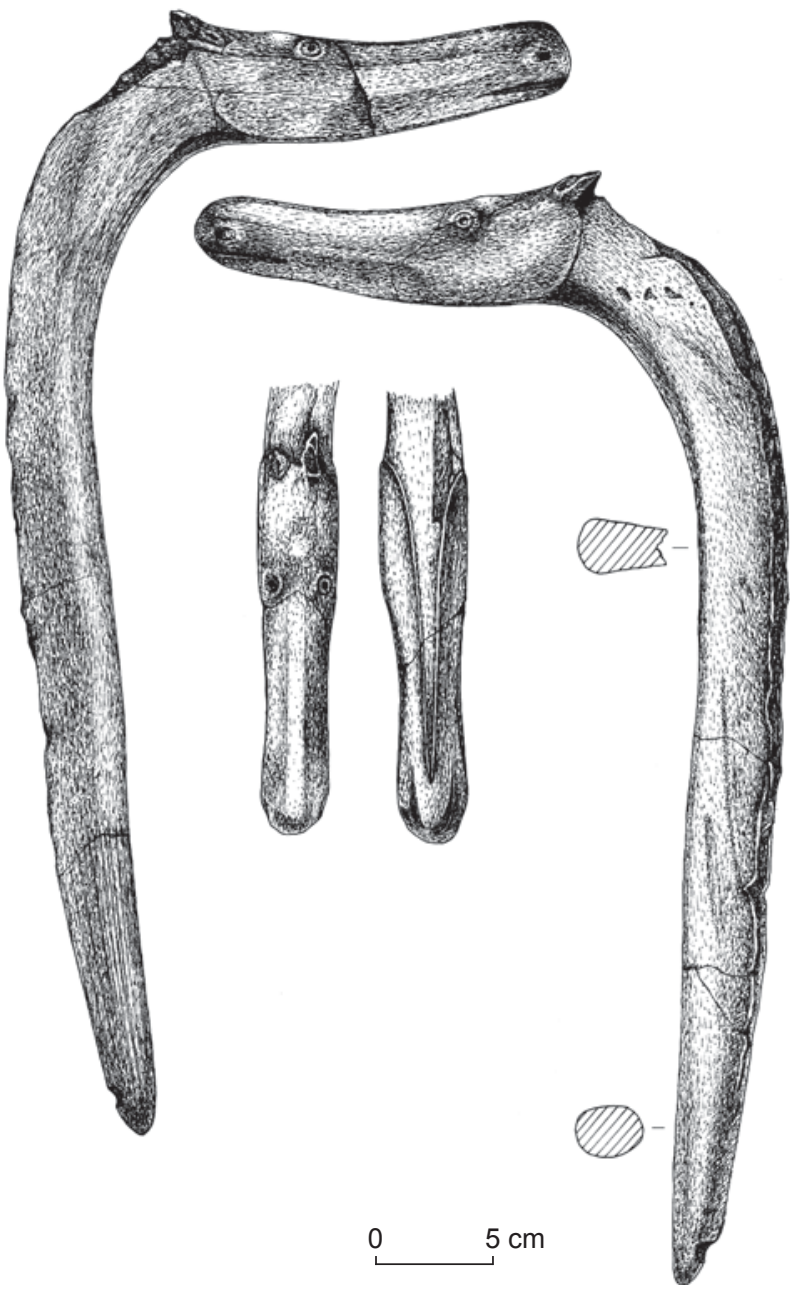

Fig. 2. Antler staff with zoomorphic finial from the burial near Pushkinsky.

end of the handle is $48 \mathrm{~cm}$; length of the finial is $18 \mathrm{~cm}$. The item consists of two parts, handle and finial, but is perceived as an integral image of an animal with rather expressively rendered muzzle (finial) and body (handle). Having combined the features of two animals (elk and horse), the artist created an abstract-syncretic image. The gracefulness of the figurine is emphasized by the elongation of the muzzle, probably caused by the shape of the antler blank.

\section{Cultural and chronological interpretation of the staff}

Parallels to the Pushkinsky staff are rare, and occur only in the forest zone of Eastern Europe in burial grounds and settlements, and in rock art.

In terms of size and style, three antler staffs from the graves of males buried in a standing position at the Oleniy Ostrov cemetery, on Lake Onega, show the greatest similarity to the staff under discussion (Gurina, 1956: Fig. 129-131; 1971, 1989). Seven more staffs, which are much smaller, have a slightly different configuration, and go back to much later period, were discovered at the Kola Oleniy Ostrov cemetery (Kolpakov, 2018: 176-177). Two antler staffs with finials in the form of elk heads were found in the layer with items of the Narva Neolithic culture at the Šventoji-3 site, in the Baltic region (Rimantene, 1975). A staff similar to the Oleniy Ostrov items was found at the Mesolithic-Neolithic burial ground of Zvejnieki in Latvia (Zagorkis, 1983: Fig. 2, 1).

Interesting sculptural representations of elk's heads (the handles have not survived) made of antler were found in the Shigir peat bog, Sverdlovsk Region, the Middle Urals (Chernetsov, Moshinskaya, 1971: Fig. 81). The cultural and chronological context of the finds is unknown, but their similarity to the artifacts from Karelia and the Baltic region, as well as to the Pushkinsky staff, is obvious. Another finial was extracted from the Shigir peat bog, which differed from the finial under study in the manner of its attachment to the handle - there was a drilled hole for fastening to the handle. Another feature of the artifact was that the animal was depicted in an abstract style, and represented a fantastic beast with frighteningly bared teeth (Savchenko, 2018). The similarity of this finial and elk-headed staffs is manifested not only in their general configuration, but also in rendering the muzzle. For example, a V-shaped notch was drawn under the lower jaw. Notably, the AMS-date obtained from the antler has made it possible to attribute this sculpture to the Mesolithic (Ibid.: 198).

Noteworthy parallels include large dagger-shaped items made of elk antler. In the Kama region, in the Neolithic burials with extended skeletons at the cemeteries of Mellyatamak V and Russky Shugan, such artifacts have a smoothly curved shape and slightly distinguished finials without zoomorphic features (Kazakov, 2011: 38, 45, fig. 106, 118). The length of one of the daggers is $40 \mathrm{~cm}$; grooves for flint blades were made along its narrow edge. Interestingly, in the Pushkinsky staff, there is also a deep groove in the back, where flint inserts might have been attached. In this form, the item could have been used as a tool, probably for sacrifice.

Thus, the area of parallels to the Pushkinsky staff does not extend beyond the forest zone from the Middle Urals to the Baltic region and Karelia. Each find is unique in its own way: it has artistic value and is associated with rather rare extraordinary complexes, mainly funerary ones.

Elk-headed staffs from the vast expanses east of the Urals are unknown. An exception are small horn staffs up to $20 \mathrm{~cm}$ long with finials in the form of bird heads, from the burials of the Sopka-2 cemetery of the Odino culture of the Early Bronze Age (in the Baraba foreststeppe region) (Molodin, 1985: 56; 2012, 166-168). 


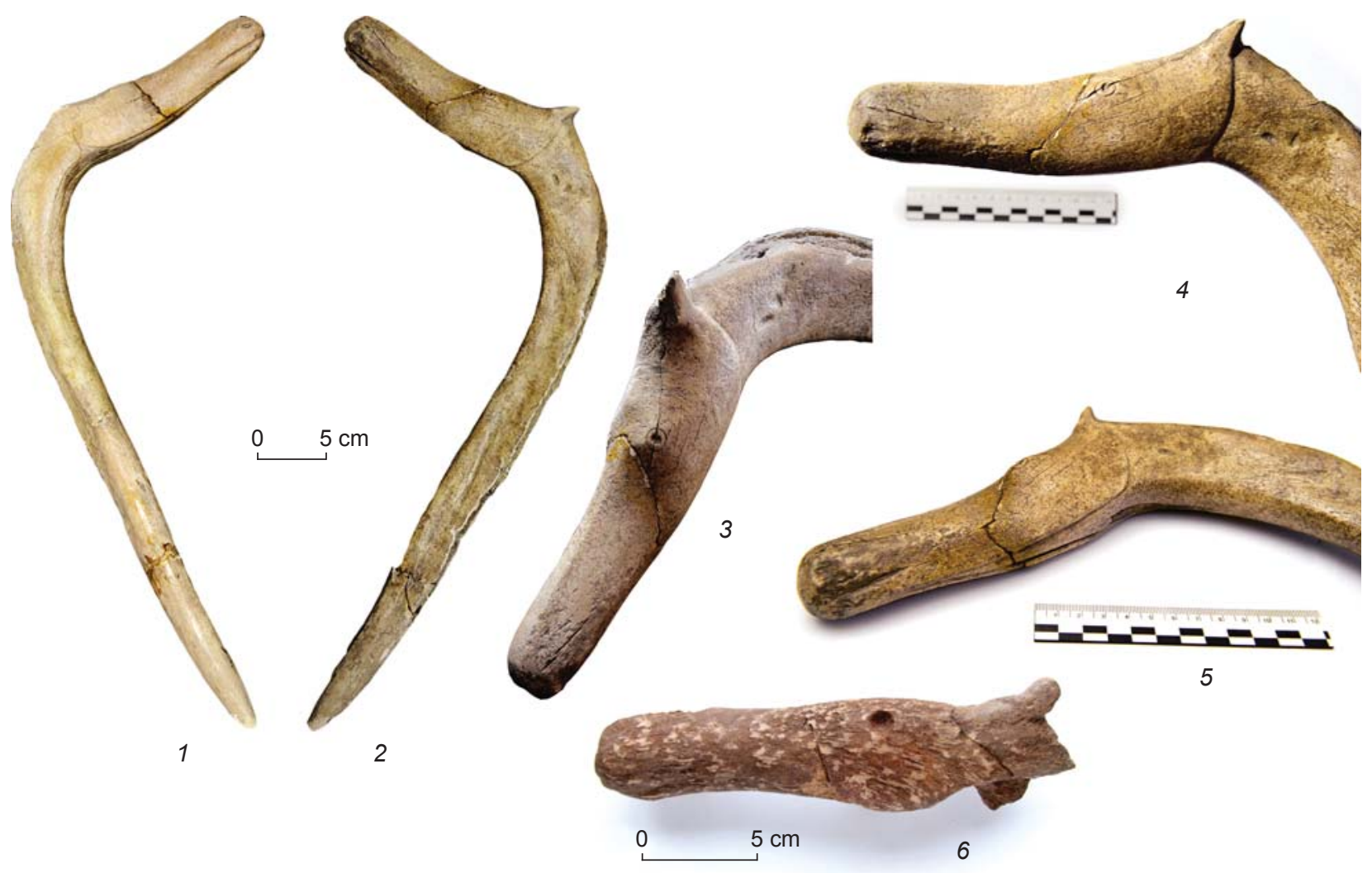

Fig. 3. Antler staffs with zoomorphic finials from the burial near Pushkinsky (1-5) and the Ekaterinovsky Mys burial ground $(6)$.

Importantly, the image of an elk played a big role in the art and mythology of the population of Siberia in the preceding stages of the Neolithic and Chalcolithic. Small-sized sculpted representations of elk carved out of bone and rendering the animal at its full height, which is a peculiarity of ancient Siberian art, are known (Okladnikov, 1950a: 280-282; 1971). Large-sized figures of elk appear at numerous monuments of rock art (Okladnikov, 1950a: 283-284; Formozov, 1969: 8293). The study of the ethnographic evidence from Siberia has made it possible to substantiate the hypothesis about a special status of elk in the life of the ancient forest population; images of elk and bear had the highest rank in the mythological hierarchy and shamanistic practices (Okladnikov, 1950b: 12-14).

In the rock art and sculpture of Europe and Siberia, the image of an elk was represented in various ways, which may have been caused by different aspects of mythology and cultic rituals. However, both in Siberia and in Eastern Europe, the image of elk was widespread; it played a leading role in the spiritual sphere of ancient communities from the Mesolithic to the Early Bronze Age, and was associated with the cultic practices of forest hunters (Kashina, 2005: 15-19). This connection is especially distinctive in the rock art of Fennoscandia. A.D. Stolyar analyzed in detail the purpose of elk-headed staffs found at cemeteries. In his opinion, these could have been used in shamanistic rituals in the same way as long pole-handles depicted on the rocks, which had a similar staff in the middle and a triangular crown at the end (Stolyar, 1983: 153-158). Many scholars consider the complexes with elk-headed staffs to be the burials of shamans (Gurina, 1956; Bogdanov, 1992; Serikov, 1998) The ideas about the magical and ritual importance of elk-headed staffs have surfaced in a number of studies based on analysis of rock art, sculptural representations, and ethnographic evidence (Zhulnikov, Kashina, 2010; Kolpakov, 2018).

An overview of the parallels to the Pushkinsky staff allows a conclusion to be drawn that the image of elk, embodied in various types of prehistoric art, was widespread in the forest zone of Eurasia in the Mesolithic, Neolithic, and Chalcolithic, along with other zoomorphic images, but occupied a leading place among them. In the light of this conclusion, the Pushkinsky staff, which was found practically in the steppe-foreststeppe, should be considered an extremely important discovery.

Several zoomorphic finials have been found in the flat-grave burial ground of Ekaterinovsky Mys, in the Samara region of the Volga. The study of this burial ground has recently started, and continues 
until now (Korolev, Kochkina, Stashenkov, 2018). Judging by first publications of radiocarbon dates, the site belonged to the Samara culture of the Early Chalcolithic (the calibrated date is late 6th to the end of the first quarter of the 5th millennium BC). One of the finials is very similar to the Pushkinsky staff. It probably formed a single whole with the lost handle (Fig. 3, 6). Similarly to the Pushkinsky staff, the image of the animal is stylized: the head is elongated, the most distinctive features of an elk (humpback nose, lower sagging parts of the lips and jaws, and small ear) are not marked (Korolev, Kochkina, Stashenkov, 2019: 395, fig. 14).

Analysis of the burial rite in the burial place where the item was discovered may help us with establishing the chronological period and cultural attribution of the Pushkinsky staff. As was mentioned above, the man was buried in a sitting position, with his knees pulled up to his chest. Such a method of burial was relatively rarely used in the cultures of the steppe zone; in the forest cultures of Eurasia it is unknown (Telegin, 1976: 17-18; Khlobystina, 1991). Scholars have observed the connection of such a rite mainly with male burials, containing rare or prestigious equipment and even human sacrifices, which suggests a special status for the buried person in the prehistoric social hierarchy (Khlobystina, 1991: 36; Potemkina, 1985: 150-153; Shilov, Maslyuzhenko, 2006: 189).

The practice of burying the deceased in a sitting position has been known since the Late Paleolithic (Kostenki), but it was most widespread in the Mesolithic and Neolithic. Burials made according to such a rite have been discovered at the Khvalynsk burial grounds of the Chalcolithic and at the sites of the Pit-Grave culture of the Early Bronze Age; they are always regarded as extraordinary (Vasiliev, 2004: 57-58). Two "seated" burials, unfortunately without grave goods, have been found in the western Orenburg region. They were located under the mound of one of the kurgans at the Labazy cemetery of the Timber-Grave culture dated to the Late Bronze Age, but did not fit the standard funerary rite of this site. Radiocarbon dating conducted in the laboratories of Moscow, Tomsk, and the University of Pennsylvania made it possible to obtain three dates for each burial. Notably, all the dates were very close, and showed the calibrated interval within the last quarter of the 7th millennium BC (Kuptsova et al., 2019: 134). According to the results of the dating, the burials were not associated with that kurgan, since they had been made long before its construction, probably during the Early Neolithic, when the Elshanka Neolithic culture was emerging (Vybornov et al., 2016: 85-90). It is worth mentioning that pottery fragments, comparable to the Elshanka ceramics, were discovered in the layer where the Pushkinsky burial was located.
The conclusion about the time when the "seated" burials appeared leads us to the issue of the chronological attribution of the above-mentioned parallels to the elk-headed staffs from the forest zone. Here, they were widespread during the Mesolithic and Neolithic. However, according to the current radiocarbon data, these chronological periods in the forest zone occurred much later than in the steppe zone (Timofeev, 2000; Zaitseva, Mazurkevich, 2016).

A large series of ${ }^{14} \mathrm{C}$ dates is available for the burials of the Onega Oleniy Ostrov cemetery, which point to the Mesolithic attribution of the site (Gurina, 1989: 30). The date of burial No. 153, where one of the most famous elkheaded staffs was found, is $7140 \pm 140 \mathrm{BP}$ (GIN-4452); other complexes are dated to a slightly later time (Zaitseva et al., 1997: 121-122). All ${ }^{14} \mathrm{C}$ dates for the Oleniy Ostrov cemetery were obtained by the scintillation method using human bone, and the reservoir effect might not have been taken into consideration while dating. However, even without the reservoir effect, the dates of these burials are unlikely to extend beyond the boundaries of the 6th millennium BC. According to the evidence from other sites, the boundary between the Final Mesolithic and the Initial Neolithic in the forest zone of Eastern Europe was rather vague, and the transition in various regions happened unevenly within the 6th millennium BC. It has been established that the emergence of the Neolithic traditions in the forest zone was associated with impulses from the southern steppe regions of Eastern Europe (Zaitseva, Mazurkevich, 2016).

For other sites, there are ${ }^{14} \mathrm{C}$ dates corresponding to the Neolithic of the northwestern regions of Eastern Europe. For example, a series of ${ }^{14} \mathrm{C}$ dates within the 6th-5th millennium $\mathrm{BC}$ was obtained from bones for a number of burials at the Zvejnieki burial ground; the date for burial No. 57 with the staff was $6825 \pm 60 \mathrm{BP}$ (Ua 3636) (Zaitseva et al., 1997: 125; Timofeev et al., 2004: 107-108). An even later date (4th to early 3rd millennium BC) characterizes the Narva culture (Rimantene, 2000).

Thus, the tradition of using elk-headed staffs emerged in the forest zone in the Mesolithic and continued to exist in a stable hunting and fishing economy throughout the Neolithic - from the 6th to the early 3rd millennium BC. In the steppe zone of Eastern Europe, in the period corresponding to the Mesolithic of the forest zone, there were already well-developed Neolithic cultures, and transition to the Chalcolithic began at the end of the 6th millennium BC (Neolit Severnoy Yevrazii, 1996: 330-348, 378).

In the steppe regions, there are fewer artifacts representing the art of the Mesolithic and Neolithic as compared to the forest zone, which is primarily explained by the fact that wooden (and often also bone) items do not survive in the steppe soils. In addition, sites such as 
burial grounds are rare in the steppe zone. However, in a few burial grounds of the Mesolithic (for example, at the Vasilievsky I and III cemeteries in the Dnieper River basin, where dozens of burials have been studied), only flint insert-blades were found (Mezolit SSSR, 1989: 122124). Individual small-sized sculptures were discovered at the sites of the Neolithic and Chalcolithic (Neolit Severnoy Yevrazii, 1996). These artifacts were made of stone, clay, or bone; on rare occasions, they render zoomorphic images. In the west of the Northern Black Sea region, anthropomorphic portable art and painted pottery were widely spread already in the Neolithic. The evidence of the artistic creativity of the population inhabiting the eastern part of the steppe belt is exclusively ornamental motifs on pottery and rare small objects of portable art. It is noteworthy that these figurines represent the image of bull or horse. The cult of these animals was common in the ritual practices of the steppe population, and later became popular in funeral rites and in arts (Formozov, 1969: 135-138; Vasiliev, Matveeva, 1979; Yudin, 2004). Deification of the horse, its role, and its place in the religion of nomads of the Early Iron Age has been analyzed in a number of studies (see, e.g., (Kuzmina, 2002: 46-73)).

Many scholars have observed the connection of artistic activities and preferred imagery in prehistoric art with the environment and the main aspects of subsistence (Okladnikov, 1950a, b; Formozov, 1969; Gurina, 1971; and others). It is obvious that during the Mesolithic, Neolithic, and Chalcolithic, the hunting activities of the population living in the steppe and the adjoining southern parts of forest-steppe differed from those of the forest regions, and were associated with different species of animals: for the inhabitants of the steppe-forest-steppe regions, of the greatest importance were aurochs, horses, and saigas (Belanovskaya, 1995: 145-147; Morgunova, 1995: 81-83; Kotova, 2002: 111-119; Yudin, 2004: 195).

\section{Conclusions}

The burial near Pushkinsky was probably made in the Early Neolithic, most likely by representatives of the Elshanka culture. The staff discovered therein is one of the most outstanding works of prehistoric art. In terms of its meaning, the staff belongs to a number of similar artifacts found mainly on the sites of the forest MesolithicNeolithic in Eastern Europe and associated with hunting cults and myth-making. At the same time, the Pushkinsky staff has some peculiarities in its style and choice of the prototype, which probably depended on the specific hunting activities of the local population inhabiting the steppe-forest-steppe. Therefore, although the ancient artist intended to create the image of a horse, and not an elk, the item itself, which is close to canon, reveals a connection with some traditions common to the entire range of such artifacts.

When analyzing artifacts in the form of staffs with zoomorphic finials, it is necessary to take into consideration the differences in chronology of the epochs in various landscape zones. Taking into account the data on the emergence of the Neolithic in the northern regions as a result of impulses from the southern areas, and on the wide occurrence in the pottery of the forest zone of many features typical of the Elshanka, Surskoy-Dnieper, and other steppe cultures, it can be hypothesized that the tradition of using curved staffs with zoomorphic finials in cultic practices originated in the steppe-foreststeppe. After that, this tradition, adapted to other natural conditions, spread to the forest cultures.

Notably, the burial in which the staff was found belonged to a man of advanced age, according to the standards of his time; judging by the position of the bones, he was buried in a sitting position. A burial of a person in a standing position has been found at the Oleniy Ostrov cemetery. The funeral rite of both burials is exceptional. The circumstances of the burial, as well as the presence of a unique artifact in the burial, indicate the high prestige of staffs with zoomorphic finials and their connection with people who were at the highest level of the hierarchical ladder, and as is known, in prehistoric societies these were ministers of religion.

\section{Acknowledgements}

This study was supported by the Russian Foundation for Basic Research (Project No. 18-09-40031). The author thanks A.I. Korolev, A.F. Kochkina, and D.A. Stashenkov for providing the photo of the staff from the Ekaterinovsky Mys burial ground, and for permission to use it in this publication. I am also grateful to A.A. Vybornov for his consultations during the preparation of this article.

\section{References}

\section{Belanovskaya T.D. 1995}

Iz drevneishego proshlogo Nizhnego Podonya. Poseleniye vremeni neolita i eneolita Rakushechniy Yar. St. Petersburg: Izd. $\mathrm{SPb}$. Gos. Univ.

\section{Bogdanov S.V. 1992}

Tokskiy zhezl. In Drevnyaya istoriya naseleniya volgouralskikh stepey. Orenburg: Izd. Orenburg. Gos. Ped. Inst., pp. 195-207.

Chernetsov V.N., Moshinskaya V.I. 1971

Drevneye iskusstvo Urala i Zapadnoy Sibiri. In Istoriya iskusstva narodov SSSR, vol. 1. Moscow: Izobraz. iskusstvo, pp. 71-82.

Formozov A.A. 1969

Ocherki po pervobytnomu iskusstvu. Moscow: Nauka. 


\section{Gurina N.N. 1956}

Oleneostrovskiy mogilnik. Moscow, Leningrad: Izd. AN SSSR. (MIA; iss. 47).

Gurina N.N. 1971

Iskusstvo neoliticheskikh plemen lesnoy polosy Yevropeiskoy chasti SSSR. In Istoriya iskusstva narodov SSSR, vol. 1. Moscow: Izobraz. iskusstvo, pp. 64-71.

\section{Gurina N.N. 1989}

Mezolit Karelii. In Mezolit SSSR, B.A. Rybakov (ed.). Moscow: Nauka, pp. 27-31. (Arkheologiya SSSR).

\section{Kashina E.A. 2005}

Iskusstvo malykh form neolita - eneolita lesnoy zony Vostochnoy Yevropy: Cand. Sc. (History) Dissertation. Moscow. Kazakov E.P. 2011

Pamyatniki epokhi kamnya v Zakamye. In Arkheologiya Povolzhya i Urala. Materialy i issledovaniya, iss. 1. Kazan: Foliant.

Khlobystina M.D. 1991

"Sidyachiye" pogrebeniya kultur Severnoy Yevrazii epokhi neolita i bronzy. KSIA, iss. 203: 32-38.

Kolpakov E.M. 2018

Losinogoloviye zhezly (topory) Severnoy Yevropy. Stratum Plus, No. 1: 163-180.

Korolev A.I., Kochkina A.F., Stashenkov D.A. 2018

Rezultaty novykh issledovaniy mogilnika Yekaterinovskiy Mys. In XXI Uralskoye arkheologicheskoye soveshchaniye: Materialy Vseros. nauchn. konf. Samara: pp. 40-42.

Korolev A., Kochkina A., Stashenkov D. 2019

The Early Eneolithic burial ground at Ekaterinovsky Cape in the forest-steppe Volga region. Documenta Praehistorica, vol. XLVI: 388-397.

\section{Kotova N.S. 2002}

Neolitizatsiya Ukrainy. Lugansk: Shlyakh.

Kuptsova L.V., Zaretskaya N.E., Morgunova N.L.,

Khokhlov A.A. 2019

Drevneishiye pogrebeniya v Orenburzhye (o dvukh zakhoroneniyakh kurgannogo mogilnika u s. Labazy). In Vestnik Moskovskogo universiteta. Ser. XXIII: Antropologiya, No. 1. Moscow: Mosk. Gos. Univ., pp. 131-139.

\section{Kuzmina E.E. 2002}

Mifologiya i iskusstvo skifov i baktriytsev. Moscow: Ros. Inst. kulturologii.

\section{Lavrushin Y.A., Spiridonova E.A. 1995}

Rezultaty paleogeomorfologicheskikh issledovaniy na stoyankakh neolita - bronzy v basseyne r. Samara. In Morgunova N.L. Neolit i eneolit yuga lesostepi Volgo-Uralskogo mezhdurechya. Orenburg: Yuzhniy Ural, pp. 177-199.

\section{Mezolit SSSR. 1989}

B.A. Rybakov (ed.). Moscow: Nauka. (Arkheologiya SSSR).

Molodin V.I. 1985

Baraba v epokhu bronzy. Novosibirsk: Nauka.

Molodin V.I. 2012

Pamyatnik Sopka-2 na reke Omi: Kulturnokhronologicheskiy analiz pogrebalnykh kompleksov odinovskoy kultury, vol. 3. Novosibirsk: Izd. IAET SO RAN.

\section{Morgunova N.L. 1984}

Raskopki Turganikskoy stoyanki. In Arkheologicheskiye otkrytiya 1982 goda. Moscow: Nauka, p. 163.

\section{Morgunova N.L. 1995}

Neolit i eneolit yuga lesostepi Volgo-Uralskogo mezhdurechya. Orenburg: Yuzhniy Ural.

\section{Morgunova N.L. 2011}

Eneolit Volzhsko-Uralskogo mezhdurechya. Orenburg: Izd. Orenburg. Gos. Ped. Univ.

Morgunova N.L., Vasilieva I.N., Kulkova N.A., Roslyakova N.V., Salugina N.P., Turetskiy M.A.,

Fayzullin A.A., Khokhlova O.S. 2017

Turganikskoye poseleniye v Orenburgskoy oblasti. Orenburg: Izd. tsentr Orenburg. Gos. Agrar. Univ.

Neolit Severnoy Yevrazii. 1996

B.A. Rybakov (ed.). Moscow: Nauka. (Arkheologiya SSSR)

\section{Okladnikov A.P. 1950a}

Neolit i bronzoviy vek Pribaikalya. Leningrad: Izd. AN SSSR. (MIA; No. 18).

Okladnikov A.P. 1950b

Kult medvedya u neoliticheskikh plemen Vostochnoy Sibiri. Sovetskaya arkheologiya, No. 14: 7-19.

\section{Okladnikov A.P. 1971}

Iskusstvo neoliticheskikh plemen Sibiri. In Istoriya iskusstva narodov SSSR, vol. 1. Moscow: Izobraz. iskusstvo, pp. 86-96.

\section{Petrenko A.G. 1995}

Rezultaty opredeleniya arkheozoologicheskikh materialov iz raskopok Ivanovskoy stoyanki. In Morgunova N.L. Neolit $i$ eneolit yuga lesostepi Volgo-Uralskogo mezhdurechya. Orenburg: Yuzhniy Ural, pp. 205-220.

Potemkina T.M. 1985

Bronzoviy vek lesostepnogo Pritobolya. Moscow: Nauka. Rimantene R.K. 1975

Khudozhestvenniye izdeliya stoyanki Shvyantoyi-3. In Pamyatniki drevneishey istorii Yevrazii. Moscow: Nauka, pp. 138-142.

\section{Rimantene R.K. 2000}

Khronologiya neolita v Litve. In Khronologiya neolita Vostochnoy Yevropy. St. Petersburg: IIMK RAN, pp. 67-68.

Savchenko S.N. 2018

Rannemezoliticheskoye rogovoye navershiye $\mathrm{v}$ vide golovy fantasticheskogo zverya iz Srednego Zauralya. Problemy istorii, filologii, kultury, No. 2: 191-207.

\section{Serikov Y.B. 1998}

Shamanskiye pogrebeniya Zauralya. In Voprosy arkheologii Urala, iss. 23. Yekaterinburg: Izd. Ural. Gos. Univ., pp. 29-47.

\section{Shilov S.N., Maslyuzhenko D.N. 2006}

Sidyachiye pogrebeniya epokhi eneolita na territorii stepnogo Pritobolya. In Voprosy arkheologii Povolzhya, iss. 4. Samara: Nauch.-tekhnich. tsentr, pp. 186-191.

Stolyar A.D. 1983

"Zhezly" onezhskikh petroglifov i ikh materialniye prototipy. In Izyskaniya po mezolitu i neolitu SSSR. Leningrad: Nauka, pp. 145-158.

\section{Telegin D.Y. 1976}

Ob osnovnykh pozitsiyakh v polozhenii pogrebennykh pervobytnoy epokhi Yevropeiskoy chasti SSSR. In Eneolit $i$ bronzoviy vek Ukrainy. Kiev: Nauk. Dumka, pp. 5-21.

Timofeev V.I. 2000

Radiouglerodniye daty i problemy neolitizatsii Vostochnoy Yevropy. In Khronologiya neolita Vostochnoy Yevropy. St. Peteresburg: IIMK RAN, pp. 81-82.

Timofeev V.I., Zaitseva G.I., Dolukhanov P.M., Shokurov A.M. 2004

Radiouglerodnaya khronologiya neolita Severnoy Yevrazii. St. Petersburg: IIMK RAN: Teza. 


\section{Vasiliev I.B. 2004}

Pogrebeniye v "poze sidya" u s. Staro-Kabanovo v Bashkirii. In Voprosy arkheologii Urala i Povolzhya, iss. 2. Samara: Samar. Gos. Univ., pp. 50-66.

Vasiliev I.B., Matveeva G.I. 1979

Mogilnik u s. Syezzheye na r. Samare. Sovetskaya arkheologiya, No. 4: 147-166.

Vybornov A.A., Andreev K.M., Kulkova M.A.,

Nesterov E.M. 2016

Radiouglerodniye danniye k khronologii neolita lesostepnogo Povolzhya. In Radiouglerodnaya khronologiya epokhi neolita Vostochnoy Yevropy VII-III tysyacheletiya do n.e. Smolensk: Svitok, pp. 74-96.

\section{Yudin A.I. 2004}

Varfolomeyevskaya stoyanka i neolit stepnogo Povolzhya. Saratov: Izd. Saratov. Gos. Univ.

\section{Zagorkis F.A. 1983}

Kostyanaya i rogovaya skulptura iz mogilnika Zveynieki. In Izyskaniya po mezolitu i neolitu SSSR. Leningrad: Nauka, pp. $138-142$.

\section{Zaitseva G.I., Mazurkevich A.N. 2016}

Vvedeniye. In Radiouglerodnaya khronologiya epokhi neolita Vostochnoy Yevropy VII-III tysyacheletiya do n.e. Smolensk: Svitok, pp. 11-13.

\section{Zaitseva G.I., Timofeev V.I., Zagorskaya I.,}

\section{Kovalyukh N.N. 1997}

Radiouglerodniye daty pamyatnikov mezolita Vostochnoy Yevropy. In Radiouglerod i arkheologiya, iss. 2. St. Petersburg: IIMK RAN, pp. 117-127.

Zhulnikov A.M., Kashina E.A. 2010

"Staffs with elk heads" in the culture of the ancient population of the Eastern Urals, Northern and Eastern Europe. Archaeology, Ethnology and Anthropology of Eurasia, vol. 38 (2): 71-78. 